\title{
HABITAT PREFERENCES OF MACROINVERTEBRATE FAUNA AMONG SEAGRASSES WITH VARYING STRUCTURAL FORMS
}

\author{
A. Gartner ${ }^{1, *}$, F. Tuya ${ }^{2}$, P.S. Lavery ${ }^{1}$, K. McMahon ${ }^{1}$ \\ ${ }^{1}$ Coastal Marine Ecosystems Research Group, Faculty of Communications, Health \\ and Science, Edith Cowan University, Joondalup 6027, Western Australia. \\ ${ }^{2}$ Departamento de Biología, Facultad de Ciencias del Mar \\ Universidad de Las Palmas de Gran Canaria \\ Email: adam.gartner@oceanica.com.au \\ *corresponding author
}

\begin{abstract}
The role of habitat structural complexity in shaping faunal communities has been of key interest for many years, principally due to the association between increased complexity and high abundances and diversity of fauna. Despite this, macroinvertebrate assemblages within seagrasses with varying morphologies and canopy structures have seldom been compared. Algal epiphytes also contribute to the structural complexity of seagrass ecosystems, a factor often overlooked in studies on seagrass structural complexity. We used artificial seagrass units (ASUs) with varying structure to determine the relative importance of 'food' versus 'structure' for macroinvertebrate fauna (Experiment 1). We also tested whether the importance of different structural components of seagrasses for macroinvertebrate fauna was consistent between seagrasses (Amphibolis griffithii, Posidonia sinuosaand Cymodocea nodosa) with naturally different complexity (Experiment 2). In Experiment 1, the treatments with the combination of food and structure together had the greater density of colonizing macroinvertebrates, compared to when either
\end{abstract}


structure or food were independently tested. In Experiment 2, the density of fauna colonizing ASUs varied among complexities of ASUs, as well as seagrasses. Generally, the highest densities of fauna on ASU's placed alongside Amphibolis griffithii and Posidonia sinuosa (species which vary greatly in morphology, but little in available surface area) were found on ASUs with artificial epiphytes, suggesting small scale variation in structure was more important than large scale variation in canopy morphology. However, there was no difference in the total density of fauna colonizing onto ASUs placed alongside Cymodocea nodosa seagrass, which morphologically has a structure similar to P. sinuosa, but much lower surface area. We conclude from these experiments that the effect of high structural complexity in seagrasses is important, in particular that provided by algal epiphytes However, when seagrass canopy surface area is limited, the effect of structural complexity may be less important for macroinvertebrate fauna than for seagrasses with high surface area available.

Key words: Structural complexity, Macroinvertebrate fauna, Seagrass, Western Australia, Canary Islands

\section{Introduction}

Globally, many near-shore coastal ecosystems, such as coral reefs, mangroves and seagrasses are being stressed as a consequence of human activities. While declines in their overall extent has been widely recognized (Waycott, et al., 2009), understanding other effects of anthropogenic stressors, such as homogenization of habitat and simplification of structural form is less well understood (Hewitt, et al., 2008). Changes will often occur to a habitat much earlier than declines in overall extent 
(Lavery, et al., 2009; Longstaff, Dennison, 1999). These changes can serve to modify the habitat such that while it still remains, there may be a reduction in the ecosystem functions it can provide (Hewitt, et al., 2008). In seagrass systems, these changes can have negative effects for the macroinvertebrate fauna that inhabit them (Gartner, et al., 2010) potentially removing an important trophic link to higher order consumers. Such changes in the macroinvertebrate assemblage are largely associated with declines in algal epiphyte biomass, leaf canopy variables and stem biomass (Bostrom, Mattila, 1999; Edgar, 1990a; Gartner, et al., 2010), which all demonstrate sub-lethal responses to anthropogenic stressors (Lavery, et al., 2009). It is hypothesized that these associations are primarily driven by a reliance on these habitat resources by macroinvertebrate fauna for food, shelter and possibly protection from predation (Gartner, et al., 2010). However, while these outcomes have been observed in field investigations thus establishing correlative evidence (Gartner, et al., 2010), our general understanding remains limited and there are few studies which have confirmed the mechanisms which drive changes in macroinvertebrate assemblages via controlled experiments.

The role of habitat structure and complexity in seagrasses is of key interest to many ecologists (Cardoso, et al., 2007; Hewitt, et al., 2008; Horinouchi, et al., 2009). Habitat structural complexity is taken here to mean the variation attributable to the absolute abundance of individual structural components (McCoy, Bell, 1991). Thus, complex habitats have many and well developed strata, while simple habitats have fewer and less developed strata (August, 1983). 
Seagrass meadows, in general, are characterised by high levels of physical complexity (Walker, et al., 1999), which in conjunction with the composition and productivity of algal epiphytes, are important aspects of seagrass ecology to explain patterns in the abundance and diversity of resident macroinverebrate fauna (Orth, et al., 1984; Sirota, Hovel, 2006; Virnstein, et al., 1984). For example, the seagrass Amphibolis griffithii, which is commonly found in near-shore waters in south Western Australia, typically has multi-stemmed canopies with leaf forming clusters. The net of interlacing stems, leaf clusters, roots and rhizome form a dense canopy, and its gaps and crevices can provide potential habitat for a variety of benthic fauna (Edgar, Robertson, 1992). The space size of these gaps and crevices relative to fauna size may hinder or facilitate some taxa and also result in exclusion of certain fauna (Bartholomew Shine, 2008)The size distribution of most macroinvertebrate fauna typically occurring in Amphibolis griffithii seagrasses ranges between 0.7 and $1.4 \mathrm{~cm}$ in length (Edgar, 1990a; Gartner, et al., 2010), while the seagrass commonly range from $30-100 \mathrm{~cm}$ in height (den Hartog, 1970). Algal epiphytes are also important components of seagrass systems and can vary between seagrasses species (Borowitzka, et al., 2006). Algal epiphytes are generally considered to have a high nutritional value for grazing organisms (Jernakoff, et al., 1996; Kitting, et al., 1984; Klumpp, et al., 1992), largely exceeding that of their host seagrasses, and so are preferred and more efficiently assimilated by macroinvertebrate fauna than seagrasses (Hyndes, Lavery, 2005). However, there may be many factors affecting particular choice of food among macroinvertebrate fauna, and selection may be driven by feeding apparatus, palatability and availability of food (Doropoulos, et al., 2009), energy content (Klumpp, et al., 1989), ease of digestion (Wylie, Paul, 1988) or other factors (Jernakoff, et al., 1996). In addition to their trophic value, epiphytes contribute to the 
structural complexity of seagrass ecosystems, a factor seldom included in studies on seagrass structural complexity.

Despite the important role that structure and food resources play in shaping macroinvertebrate densities, our understanding of their interacting effects remains limited. Two important investigations by Bologna and Heck (1999) and Bostrom and Mattila (1999) attempted to disentangle the relative importance of food and structure in seagrass systems. Both studies indicated for most herbivorous and omnivorous taxa that the nutritional value of algal epiphytes primarily accounted for macroinvertebrate densities, while structure appeared to play only a limited role in determining faunal densities (Bologna, Heck, 1999). These results contrast with other evidence highlighting the importance of structure as a driver of faunal recruitment in seagrass systems (Edgar, 1990b; Edgar, Robertson, 1992; Jernakoff, Nielsen, 1998; Nakaoka, 2005), and suggest that a greater understanding of the role of seagrass structure is still required.

While the abundance and richness of macroinvertebrate assemblages appears to be proportional to the amount of seagrass available (including leaf and stem area), this relationship is less clear when referring to the type or shape of structure of the seagrass. The shape of a particular habitat is not necessarily directly related to the density of habitat, and although some researchers have distinguished between shape and density as separate components of structural complexity (McCoy, Bell, 1991; Sirota, Hovel, 2006), they have rarely been treated as such in ecological studies. However, dissimilarities in the species richness, biomass and secondary production of macrofaunal assemblages associated with seagrasses such as Posidonia and 
Amphibolis (Edgar, 1990a), which contrast significantly in their morphology, is likely at least in part due to variations in structural form. Because different seagrass species have evolved to a range of structural morphologies (Hemminga, Duarte, 2000), the role of structural form may also influence the abundance of macroinvertebrates (Sirota, Hovel, 2006) and this may even vary between different types (i.e. species) of seagrasses.

In the present study, we investigated the role of 'food' and 'structure' on the abundance patterns of macroinvertebrate fauna inhabiting seagrasses, as well as assessed whether the different structural components of seagrasses are equally important between types of seagrasses with naturally different structural complexity. We used a combination of field-based experiments in different locations to manipulate available food and structural elements of these two features of seagrass habitat.

\section{Methods}

\section{Study area}

Experiment 1 was conducted at Marmion Marine Park (April 2008) in Western Australia, located within a near-shore $(<500 \mathrm{~m})$ semi-enclosed coastal lagoon, dominated by seagrass, sand and macroalgal reef habitats. The experiment was situated immediately adjacent to extensive mono-specific Amphibolis griffithii

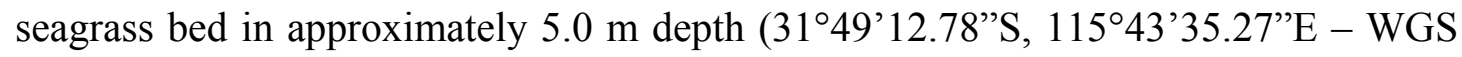
84 datum; Figure 1). A. griffithii has a vertical branching stem that holds terminal leaf clusters (Cambridge, 1999). There are generally 2-5 leaves per cluster and 6-20 clusters per vertical stem (Cambridge, 1999; Carruthers, 1999; Ducker, et al., 1977). The maximum size of leaves is $100 \times 10 \mathrm{~mm}(\mathrm{~L} \times \mathrm{W})$, stem height ranges from 30$100 \mathrm{~cm}$ (den Hartog, 1970). 
Experiment 2 was carried out at the same site in the Marmion Marine Park alongside separate (mono-specific) Amphibolis griffithii and Posidonia sinuosa meadows in March 2008. P. sinuosa generally has 1-3 ribbon shaped leaves per shoot which are 4$11 \mathrm{~mm}$ wide and generally between 30 and $70 \mathrm{~cm}(\max .120 \mathrm{~cm})$ in length (Cambridge, Kuo, 1979). This experiment was also carried out at Arinaga (Gran Canaria, Canary Islands, Spain; Figure 1) in September 2008 (seasonally corresponding with Australian summer), within a Cymodocea nodosa seagrass meadow. This site was situated in an extensive mono-specific $C$. nodosa seagrass bed in approximately $7.0 \mathrm{~m}$ depth $\left(27^{\circ} 51^{\prime} 26.33^{\prime \prime} \mathrm{N}, 15^{\circ} 23^{\prime} 12.09^{\prime \prime} \mathrm{W}\right.$ - WGS 84 datum). The strap-like form of $C$. nodosa is similar to P. sinuosa in structure, with typically 23 leaves per shoot; however, its length is shorter, generally ranging from 10 to $18 \mathrm{~cm}$ (Tuya, et al., 2006) and width narrower, being approximately $2 \mathrm{~mm}$ (personal observations). Cymodocea nodosa is typically found from 5 to $15 \mathrm{~m}$ depth and ranges in density between 200-700 shoots $\mathrm{m}^{-2}$ (Barbera-Cebrian, et al., 2005). No seagrass species exist in the Canary Islands with similar morphological structure to Amphibolis species (Espino, et al., 2006).

Amphibolis griffithii can support a diverse range and large biomass of algal epiphytes with more than 90 taxa reported (Lavery, Vanderklift, 2002) and epiphyte loads of approximately $0.998 \mathrm{~g} \mathrm{~g}^{-1}$ DW Amphibolis stem and leaf. (Jernakoff, Nielsen, 1997). In contrast, Posidonia typically support slightly fewer epiphytic taxa but much lower biomass than Amphibolis (Lavery, Vanderklift, 2002), with Jernakoff, Nielsen (1997) reporting 45 species, and mean biomass of $0.05-0.02 \mathrm{~g} \mathrm{~g}^{-1}$ DW Posidonia sinuosa leaf in a study off Western Australia. Comparably, epiphytic loads on Cymodocea 
nodosa range in the study area between $0.05-0.25 \mathrm{~g}$ DW epiphytes per g DW of leaf (F. Tuya, unpublished data) and appear to naturally have much lower diversities of taxa (Reyes, Sanson, 2001).

\section{Experiment 1: disentangling the role of 'food' versus 'structure' as drivers of}

\section{faunal colonization}

To determine the relative importance of food vs. structure for patterns of density of macroinvertebrate fauna, we used Artificial Seagrass Units (ASUs), following a design similar to that of Bologna \& Heck (1999). Three treatments were established: (i) High structure, High food (HH); (ii) High structure, Low food (HL); and (iii) Low structure, Low food (LL). Structure was manipulated by the design of the ASU and food through the provision of algal epiphytes to the ASU (Figure 2a). Note that the Low food treatments had no epiphytes attached, however they were named 'Low' under the assumption that a very small amount of periphyton was likely to grow on all ASU leaf surfaces (subsequently quantified as negligible).

Five replicates of each experimental treatment were deployed randomly along the edge of an Amphibolis griffithii meadow (surrounded by un-vegetated meadow), for a total of 15 experimental units. The next closest reef habitat to the experimental array was $\sim 120 \mathrm{~m}$ apart, with dense $A$. griffithii meadow occurring between the reef and the experimental array. ASUs were placed at a spacing interval of approximately $4 \mathrm{~m}$ to ensure independence. Based on results from pilot studies, ASUs were deployed for ten days to undergo faunal colonization/recruitment, after which they were collected (by lowering a calico bag of finely woven unbleached cotton, mesh size $<0.5 \mathrm{~mm}$, over the entire ASU to retain all fauna within) and faunal density determined, as per 
Gartner et al. (2010). Based on this design, we attempted to evaluate the following predictions regarding the density of macroinvertebrate fauna among ASUs:

$\mathbf{H}_{1}$ Neither food or structure affect macroinvertebrate densities: $\mathrm{HH}=\mathrm{HL}=\mathrm{LL}$

$\mathbf{H}_{2}$ Primarily, structure affects macroinvertebrate densities: $\mathrm{HH}=\mathrm{HL}>\mathrm{LL}$

$\mathbf{H}_{3}$ Primarily, food affects macroinvertebrate densities: $\mathrm{HH}>\mathrm{HL}=\mathrm{LL}$

$\mathbf{H}_{4}$ Both food and structure affect macroinvertebrate densities: $\mathrm{HH}>\mathrm{HL}>\mathrm{LL}$

All ASUs had a rectangular configuration $(\sim 15 \times 20 \mathrm{~cm})$ with artificial seagrass attached in an evenly spaced grid formation at densities approximating naturally occurring seagrass (actual densities given below for each treatment). Artificial seagrass were constructed using buoyant smooth plastic polyribbon for leaves and $27 \mathrm{~cm}$ cable ties $(0.2 \mathrm{~cm}$ width) for stems (where required, as LL did not have stems). Each HH and HL units had additional surface area due to epiphyte material and cable ties $\left(\mathrm{LL} \sim 3975 \mathrm{~cm}^{2}\right.$; HH \& HL $\sim 5257 \mathrm{~cm}^{2}$ ). To compensate this additional surface area, data were analysed using an analysis of covariance (ANCOVA, see below). Surface area was calculated by measuring the surface area of each individual component of each ASU treatment, multiplied by the total number of leaves, stems or shoots of each ASU treatment, respectively. Each LL unit had eight 'shoots', consisting of 4 leaf blades per shoot (each blade was approx. $51.8 \mathrm{~cm}$ in length by 1.2 cm width), closely resembling Posidonia sinuosa seagrass (Figure 2a). These were attached directly to steel mesh by small cable ties at the base of each shoot. $\mathrm{HH}$ and HL units consisted of seven 'stems' with 16 leaves each (approx. $12.9 \mathrm{~cm} \times 1.2 \mathrm{~cm}$ ) arranged in five clusters of three to four leaves each, therefore resembling Amphibolis griffithii seagrass (Figure 2a). These were attached to plastic cable ties (surface area 
$26.4 \mathrm{~cm}^{2}$ ), which were fastened at the base to steel mesh. The red algal epiphyte Hypnea sp., was attached to each artificial stem in the HH units $(\sim 1.6 \pm 0.09 \mathrm{~g}$ wet weight per stem, approximately equal volume displacement as artificial epiphytes attached to HL treatments) to provide a natural food source. Hypnea sp. was selected for its complex morphological form (filamentous), common occurrence in Amphibolis seagrass meadows in the study area (Lavery, Vanderklift, 2002) and as it has been reported previously as preferred food source for herbivorous marine amphipods (Duffy, Hay, 1991). Hypnea was also selected as reported findings suggest that species within this genera do not contain secondary metabolites that may be toxic to macroinvertebrate fauna (Brawley, Aday, 1981; Wylie, Paul, 1988). Prior to placement into the experimental array, Hypnea were treated with $\mathrm{CO}_{2}$ (bubbled through seawater within an enclosed container for one minute in the laboratory) to remove any fauna (Jernakoff, Nielsen, 1998).

To create additional structure, but without adding food, HL units had artificial epiphytes attached to the stem immediately above the lowest cluster. Two cm length of clear plastic tinsel was used to construct the artificial epiphytes (adding approx. $228 \mathrm{~cm}^{-2}$ of surface area per stem, comparable to the surface area of Hypnea sp. in $\mathrm{HH})$ and attached with a single small cable tie.

In addition to the three treatments, five replicate seagrass units with live $A$. griffithii seagrass and algal epiphytes were deployed for ten days (8 stems per unit and defaunated using $\mathrm{CO}_{2}$, as per Jernakoff, Nielsen, 1997). Defaunated Amphibolis griffithii plants were deployed alongside the main experiment to ensure that the effect of ASUs treatments on the density of fauna could be attributed at least in part to food 
and/or structure, and were not an unwanted artefact of the ASUs. These were collected and processed as above.

Differences in total epifaunal density among treatments (fixed factor), and the density of amphipods, decapods and gastropods were tested using one-way ANCOVA. ANCOVA is a general linear model with a continuous outcome variable (density) and two or more predictor variables where at least one is continuous (here, ASU surface area) and at least one is categorical (here, structural treatment). ANCOVA was used to test the main and interaction effects of the factors, while controlling for the effects of the covariate. Natural log transformations were applied where data did not conform with the underlying assumptions of ANCOVA (Quinn, Keough, 2002). Fisher's LSD post-hoc comparison tests were used to specify where differences among treatments lay. Note that the mean density of macroinvertebrate fauna recruiting onto the 'Natural' treatment were not included in this analysis, as it was only measured to better understand the effectiveness of ASUs.

Experiment 2: the effect of seagrass structural variation as drivers of faunal colonization

Experiment 2 was carried out in three seagrass meadows at two different locations (Hillarys, Western Australia - Amphibolis griffithii, Posidonia sinuosa and Canary Islands, Spain - Cymodocea nodosa). ASUs were constructed to reflect different levels of seagrass complexity. Four experimental treatments were placed adjacent to each meadow type (Figure 2b): (i) ASUs with leaves in clusters and artificial epiphytes, attached to a stem (High plus); (ii) ASUs with leaves in clusters, attached 
to a stem (High); (iii) ASUs with leaves not in clusters, attached to a stem (Moderate); and (iv) ASUs with leaves not attached to a stem (Low).

Five replicates of each experimental unit were randomly placed alongside the seagrass meadow edge, spaced approximately $4 \mathrm{~m}$ distance between adjacent ASUs. ASUs were deployed for ten days, after which time they were collected following the procedures outlined for Experiment 1. ASUs were also constructed using materials and dimensions described previously for Experiment 1 (except Moderate treatments, where dimensions are provided below). Each Low unit had eight shoots consisting of 4 leaf blades per shoot (each blade was approx. $51.8 \mathrm{~cm} \times 1.2 \mathrm{~cm}$ ), as per Experiment 1 (Figure 2b). Moderate treatments were created by attaching 8 leaves (each approx. $25.8 \mathrm{~cm}$ in length by $1.2 \mathrm{~cm}$ in width), to a cable tie 'stem' $(33 \mathrm{~cm})$. High units consisted of 16 leaves $(\sim 12.9 \mathrm{~cm} \times 1.2 \mathrm{~cm})$ set in five clusters of three to four leaves each attached to plastic cable ties (surface area $\sim 26.4 \mathrm{~cm}^{2}$ ). Each Moderate and High unit had 8 stems. High plus units were constructed as per High units, except they had seven stems per unit, as well as artificial epiphytes attached to the stem immediately above the lowest cluster. Two cm length of clear plastic tinsel was again used to construct the artificial epiphytes (adding $\sim 228 \mathrm{~cm}^{-2}$ surface area per stem).

In addition, five replicate natural epifauna samples from each seagrass species (Amphibolis griffithii, Posidonia sinuosa and Cymodocea nodosa) were also collected haphazardly from meadows adjacent to the experimental arrays, to provide a baseline to compare faunal colonization against. These were collected and processed as per Brearley et al. (2008), by lowering a unbleached woven cotton bag with a quadrat $\left(0.04 \mathrm{~m}^{2}\right)$ over the seagrass canopy, cutting the seagrass at the base of the stem, 
immediately above the sediment surface, and then closing the calico bag to retain the mobile fauna within (Brearley, et al., 2008). Epifauna were sorted and counted under a dissecting microscope into identifiable taxonomic units to class/order level (Gartner, et al., 2010) and standardized to leaf surface area, which was measured in the laboratory.

Data for total macroinvertebrate assemblage density, and the density of amphipods, decapods and gastropods (dependant variables) were analysed separately among treatments (categorical predictors; main factors 'habitat' and 'structure') using twoway ANCOVAs. ASU surface area was the continuous predictor variable. Due to low density colonization onto ASUs in the A. griffithii and P. sinuosa meadows, gastropods were analysed separately using one-way ANCOVA to test for differences among structures in the $C$. nodosa meadow only. Similarly for decapods, colonization onto ASUs placed alongside $P$. sinuosa was too low to meaningfully compare this treatment with other seagrass species and was subsequently excluded from analysis. Transformations were applied where data did not conform with the underlying assumptions of ANCOVA (Quinn, Keough, 2002). Fisher's LSD post-hoc comparison tests were used to specify where differences among treatments lay.

\section{Results}

Experiment 1: Disentangling the role of 'food' versus 'structure' as drivers of faunal colonization

Mean macroinvertebrate density was significantly greater in the High structure and High food $(\mathrm{HH})$ treatments $(50.2 \pm 3.6$ individuals, mean $\pm \mathrm{SD})$ compared with $34.6 \pm$ 6.6 individuals in the High structure and Low food (HL) and 9.2 \pm 3.2 individuals in 
the Low structure and Low food (LL; Figure 4a, Table 1). Densities of epifauna in the natural and defaunated natural samples were greater than in the experimental ASUs when standardised to leaf surface area per $\mathrm{m}^{2}(485 \pm 14.6$ and $387 \pm 74.4$ individuals respectively).

The response of different taxa to the food and structure treatments varied (Figure $4 \mathrm{~b}$,

c, d). The response of amphipods, which colonized onto ASUs in the greatest density, differed to that of total assemblage density: there was no difference between $\mathrm{HH}(29 \pm$ 43 individuals $)$ and HL (24.6 \pm 5.6 individuals $)$ treatments, though, density in LL $(9.24 \pm 4.0$ individuals) was significantly lower than both $(\mathrm{HH}=\mathrm{HL}>\mathrm{LL} ; \mathrm{p}<0.05$ Table 1). Density of decapods in HH was significantly greater than in LL (HH > LL; $\mathrm{p}<0.05$; Table 2), although no significant difference was detected between $\mathrm{HH}(8.2 \pm$ 2.2 individuals $)$ and HL (4.6 \pm 1.5 individuals $)$, or HL and LL $(1.1 \pm 0.8$ individuals $)$. The number of gastropods onto the ASU was too low to statistically compare between treatments or to derive meaningful trends from.

Experiment 2: the effect of seagrass structural variation as drivers of faunal colonization

Comparing complexity among ASU treatments, the mean number of intersection points for the High plus treatment was greatest in the lower part of the canopy ( 0 to 20 $\mathrm{cm}$ height), which was reflected in a very high $\mathrm{CV}$ value (19 and 12 between $0-10 \mathrm{~cm}$ and $12-20 \mathrm{~cm}$ respectively; Figure 5a). This area of the ASUs incorporated the artificial epiphyte material. In the High treatments, the highest number of intersections occurred between 12 and $30 \mathrm{~cm}$ height, indicating the middle of the ASU canopy had the greatest complexity (Figure 5b). The $\mathrm{CV}$ in this component of the High treatment 
(up to 0.8) was greater than in the Moderate treatments (up to 0.5). Although, the Moderate ASU treatment generally had a similar number of intersection points distributed across the height of the canopy as per the High ASU, the architectural arrangement of leaves between High and Moderate ASUs also differed (Figure 5b). For the Low ASU treatment, there were a uniform number of intersection points (4), indicating no variation in complexity and reflected by a $\mathrm{CV}$ of 0 .

The mean total density of fauna colonizing onto the ASU treatments (High plus, High, Moderate and Low) placed alongside three seagrass meadows (Amphibolis griffithii, Cymodocea nodosa and Posidonia sinuosa) ranged from $2.8 \pm 0.5$ individuals in the P. sinuosa Low treatment to $117.8 \pm 0.4$ individuals in the $C$. nodosa High plus treatment (Figure 6). The results of two-way ANCOVA indicated a significant interaction between Structure and Habitat, suggesting that the form of the ASU structure had an effect on macroinvertebrate densities, but the effect was dependent upon the habitat in which ASUs were placed alongside (Structure $\mathrm{x}$ Habitat, $\mathrm{p}<0.05$; Table 1). A similar interaction term was demonstrated in testing for differences among the mean density of the numerically dominant fauna: amphipods and decapods (Table 1); however, responses varied among these taxa (Figure 6).

The mean density of total individuals collected from ASUs placed alongside the $A$. griffithii meadow was significantly greater in High plus treatments (i.e. high structural complexity with artificial epiphyte) than in the less complex ASU treatments $(\mathrm{p}<$ 0.05; Table 1, Figure 6a). There were no significant differences among the other three treatments (High, Moderate or Low). Similar trends $(\mathrm{p}<0.05$; Table 1) were found for both amphipod and decapod densities (Figures $7 \mathrm{~b}, \mathrm{c}$ ). The number of gastropods 
onto the ASU was too low to statistically compare between treatments or to derive meaningful trends from.

Although the quantity of colonizers was lower, trends for the total density of fauna collected from ASUs placed alongside the Posidonia sinuosa meadow were largely consistent with those placed alongside the A. griffithii meadow, with the High plus treatment having significantly more colonizers than all other treatments, but no difference between High and Moderate treatments. However, the density of fauna in the Low treatments was significantly lower than all other treatments $(\mathrm{p}>0.05$; Table 1). The density of amphipods varied between complexity treatments: High plus treatments had the greatest density, being significantly higher than High and Low treatments; no differences were detected between High and Moderate treatments; but Low was significantly lower than the Moderate treatment.

The effect of ASU treatments placed in Cymodocea nodosa meadow contrasted to those collected from either Amphibolis griffithii or Posidonia sinuosa meadows. There was no significant difference in the total density of fauna and amphipods (two-way ANCOVA, $\mathrm{p}>0.05$; Table 1, Figure 6a, b, and d respectively). However, the density of decapods was significantly lower in the Low structure ASUs, compared to all other treatments, which were similar to each other (two-way ANCOVA, $\mathrm{p}<0.05$; Table 2, Figure 6c).

There was also a large variation in the total number of individuals colonizing onto ASU treatments among habitats, relative to the mean density of individuals in the surrounding natural seagrass habitats. Per leaf surface area, the mean density of fauna 
colonizing on ASUs placed alongside A. griffithii differed only by 7 - 19\% (Figure 7) of densities in the surrounding natural seagrass meadow. The difference was much greater in ASUs placed alongside C. nodosa and P. sinuosa, in which densities in the surrounding natural seagrass meadow ranged 173 - 197\% greater than densities colonizing onto ASUs.

\section{Discussion}

\section{Importance of 'food' and 'structure' for seagrass epifauna}

Understanding mechanisms which regulate the density of macroinvertebrate fauna is important to understanding how systemic changes, such as those associated with disturbance, can affect them. The results of the 'Food' versus 'structure' experiment indicate that the canopy structure provided by seagrass leaves, stems and algal epiphytes, and epiphytic algal, most likely as a food resource, are important factors for habitat selection of Amphibolis griffithii seagrass epifauna. Thus, the hypotheses $\mathrm{H}_{4}$ : both food and structure affect macroinvertebrate densities was retained.

Increased complexity is likely to provide additional refuge value, either as protection from predation (Heck, Orth, 2005) or specialist habitat niche (Edgar, Robertson, 1992), and live algal epiphytes are likely to provide trophic resources. These results are consistent with studies by Bologna \& Heck (1999) and Bostrom \& Mattila (1999) which demonstrated that the primary effect of epiphytes on macroinvertebrate fauna lie in their trophic role over their refuge value, but also highlight that canopy structure, inclusive of leaf clusters and epiphytic material, was similarly important. The seagrass analogues used in the present experiment provided a larger scale 
variation in architectural complexity than the ASUs used in these other studies, which may account for the increased value of structure to the epifauna.

Amphipods, gastropods and decapods, which numerically dominate the Amphibolis griffithii assemblage in the study area, constitute an important trophic link in seagrass systems (Jernakoff, et al., 1996). Trends varied between these taxa in response to the ASU treatments. Amphipod densities were similar in the HH and HL ASU treatments, but were higher than the LL treatments suggesting selection was based on structural preferences and not on potential food resources. While amphipod diets are variable (Jernakoff, et al., 1996), most often they are considered grazers, preferentially consuming the fine layer of microalgae from seagrass leaf surfaces (Howard, Edgar, 1994). Although the level of taxonomy here precludes a more detailed understanding of individual species preferences, dietary preference for periphyton over epiphytic macroalgae might suggest macroalgae were primarily a source of refuge for amphipods. Trends for decapod densities, predominantly caridean shrimp, were more similar to trends in overall density (Figure 4), with these fauna showing a preference for live epiphytic material and complex structure. Decapods are generally considered detritivores or predators of meiofauna (Vumazonke, et al., 2003). Thus, shrimp dietary preferences do not adequately explain higher relative densities in this treatment. Recent studies (Horinouchi, et al., 2009; Warfe, Barmuta, 2006) have highlighted that contrary to general held expectations of structure assisting the prey in habitat protection, fish predatory efficiency can also be enhanced by a structurally complex macrophyte assemblage through improved capacity for ensnaring prey. It is possible that caridean shrimp here may have been using the complex structure of the ASUs in much the same way to ambush prey. 
The experimental design used here differed slightly to that used by Bologna \& Heck (1999). Here, ASUs were deployed immediately adjacent to seagrass canopy, rather than being independent from the meadow, removing immediate choice among multiple habitats (ASU treatments). However, we do not believe this confounds either the interpretation or strength of results. Because fauna in seagrass habitats have high turn-over rates ( $>30 \%$; Edgar 1992), the probability of any individual fauna coming into contact with any one treatment were relatively high, given the level of replication and random allocation of ASUs. That results found here contrast with those of Bologna \& Heck (1999) is unlikely a consequence of slight differences in the layout of the experimental array. The greater density of fauna in defaunated A. griffithii seagrass $(387 \pm 74.4$ individuals $)$ compared with ASU treatments also demonstrates that faunal colonization onto ASUs was more likely associated with food and structural resources and not an artefact of ASUs. Had faunal densities on ASU treatments exceeded defaunated seagrass, then this would suggest that ASUs were attracting fauna for a reason other than food or habitat.

\section{The effect of seagrass structural variation on epifaunal colonization}

Trends in epifaunal densities varied between different analogues of structural complexity, and these trends varied between taxa. Importantly, we found that the species of seagrass in which ASUs were placed alongside affected colonization patterns, with similarities in colonization patterns of most taxa in Amphibolis and Posidonia seagrass, but substantial differences in trends in the density and types of taxa colonizing onto ASUs placed alongside Cymodocea seagrass. 
In the Amphibolis griffithii meadow, the most structurally complex treatment (High plus) had greatest densities of epifauna. This complexity was driven by artificial epiphytes, which by surface area, only comprised a very small component (approx. 4.3\%) of the overall ASU structure, but potentially can supply an additional refuge or habitat niche (Edgar, 1990a). These results suggest that faunal colonization patterns associated with structure in $A$. griffithii are most likely being driven by relatively fine scale structural differences provided by epiphytic algae, rather than the much larger variations in overall plant morphology. However, the effect of epiphyte 'baffling' may also serve to increase macroinvertebrate densities (Howard, Edgar, 1994), where-by the high complexity associated with the artificial epiphyte structures may lead to accumulation of nutrient rich particles, including microalgae, on the epiphytic surface (Howard, Edgar, 1994), providing a food resource for detrital or algal grazers. The effect of baffling may also catch passively dispersing invertebrates (Hannan, 1984).

The absence of difference in epifauna colonization to ASUs deployed in Cymodocea nodosa seagrass meadow suggests epifauna from this meadow had no preference for a specific seagrass analogue. When standardized against leaf surface area, the density of epifauna on ASU treatments was similar to that in the natural $C$. nodosa meadow (Figure 7), unlike those deployed in Amphibolis griffithii and Posidonia sinuosa, which were almost an order of magnitude lower than in the natural seagrass (Figure 7). This suggests that the refuge provided by structure in the $C$. nodosa system was important for epifauna density, but that the specific structural arrangement of leaves and the presence of algal epiphytic structure were not. Only decapods showed lower densities in Low treatments, possibly because this treatment may have removed any predatory advantage (Horinouchi, et al., 2009) that shrimp had over other taxa. 
If the gross architectural complexity is of most critical importance in driving these trends in macroinvertebrate density, then we would have expected trends in the $P$. sinuosa and C. nodosa meadow to be much more similar, and those in A. griffithii to differ. This theory would assume epifauna are capable of demonstrating either a genetic or learned habitat preference (Beltman, Metz, 2005) for seagrass structure. For example, habitat selection by the isopod Idotea may reflect a life history shaped by abiotic factors rather than biotic (predation), while the anti-predator behavior of Erichsonella may have evolved as a result of consistently high rates of fish predation (Bostrom, Mattila 1999). This might explain trends in P. sinuosa and A. griffithii as fauna appear to be responding to heterogeneity associated with the artificial epiphytic structure (possibly to avoid predation); however, it does not adequately account for trends in $C$. nodosa. Competitive exclusion offers an alternative explanation. $C$. nodosa habitat has a lower seagrass leaf surface area $\left(0.13 \mathrm{~m}^{2}\right.$ per $\left.0.04 \mathrm{~m}^{2}\right)$ and algal epiphyte biomass (Reyes, Sanson, 2001, estimated $52.6 \mathrm{~g} \mathrm{DW} \mathrm{m}^{-2}$ ) than $P$. sinuosa (approximately $0.58 \mathrm{~m}^{2}$ per $0.04 \mathrm{~m}^{2}$ and algal epiphytes exceeding $120 \mathrm{~g} \mathrm{DW} \mathrm{m}^{-2}$, Collier et al. 2008). This raises the possibility that epifauna in C. nodosa were space limited, relative to those in the $P$. sinuosa meadow, and that architecture of the host plant would be less important for fauna that are limited by space resulting in a more even distribution of faunal colonizers across the ASU treatments. In Gran Canaria, seagrass macroinvertebrate fauna have evolved within a habitat with simple architecture (C. nodosa), whereas in Marmion Marine Park, fauna have evolved within a mosaic of seagrasses with a variety of morphologies ( $P$. sinuosa and $A$. griffithii). It is likely that macroinvertebrate fauna within the Marmion Marine Park have evolved an ability to select complexity at different levels, relative to fauna in 
Gran Canaria, which had more arbitrary selective processes among habitat complexity. Predatory pressures, potentially learned through habitat conditioning (Beltman, Metz, 2005), and competitive exclusion as a consequence of available substrate, are likely to be important local drivers underpinning this evolutionary process (Bostrom, Mattila, 1999). These results highlight the importance of variation in the physical structure between seagrass species and that their effects on faunal colonization cannot be assumed based on seagrass structure alone.

\section{Conclusion}

Many seagrasses show physiological and morphological responses to a perturbation prior to ultimate loss in seagrass extent. Declines in the quality of seagrass habitat could include loss of leaves or epiphytic material, which this research has indicated would likely reduce both the available habitat and food for many macroinvertebrate fauna. In addition, this research has demonstrated that changes in complexity associated with small scale structures, such as algal epiphytes, is extremely important for these fauna and reductions may lead to declines in their abundances.

\section{Acknowledgements}

Comments and advice by K. Heck and C. Bostrom are much appreciated. We are particularly grateful to numerous divers including A. Verges and C. Doropoulos for time and assistance with fieldwork and the laboratory space and materials afforded by the University de Las Palmas. This research was funded by the Strategic Research Fund for the Marine Environment, Western Australian Marine Science Institute, 
Department of Environment and Conservation, Western Australia and the Holsworth Wildlife Research Fund. FT was supported by the 'Ramón y Cajal' program from the Spanish

Government. 
Figure 1: Study locations in Hillarys, Western Australia and Arinaga, Canary Islands.

Figure 2: Schematic representation of the artificial seagrass treatments used in a) Experiment 1; and b) Experiment 2.

Figure 3: Diagrammatic representation of the complexity index used to measure complexity among ASU treatments. Complexity was measured in $2.0 \mathrm{~cm}$ graduals over the height of each stem, as the number of points (leaf and stem) intersected horizontally, creating an index of complexity $(n=5)$. Data were then compared using the coefficient of variation, to assess for differences among treatments.

Figure 4: Results from Experiment 1. Mean density of macroinvertebrate fauna (total, amphipod, decapod and gastropod per ASU) in treatments (High food, High structure: HH; High food, Low structure: HL; and Low food, Low structure, LL). Shared letters across the top of bars indicate no significant difference between treatments (one-way ANOVA, $p<$ 0.05). NS indicates a non-significant outcome of ANOVA. Error bars denotes +SD of means.

Figure 5: Mean number of intersections (cross points) for each ASU treatment (high plus, high, moderate and low; $n=5)$. The coefficient of variation $(\mathrm{CV})$ for each treatment is provided to the right of bars. Error bars denotes $+\mathrm{SE}$ of means.

Figure 6: Results from Experiment 2. Mean density of macroinvertebrate fauna (total, amphipod, decapod and gastropod) in ASUs treatments (high plus, high, moderate and low) from ASUs placed alongside three different meadows (Amphibolis griffithii, Posidonia sinuosa and Cymodocea nodosa). Shared letters across the top of bars indicate no significant difference between treatments (ANCOVA, $\mathrm{p}<0.05$ ). NS indicates a non-significant outcome of ANOVA. Error bars denotes $+\mathrm{SE}$ of means.

Figure 7: Mean number of individuals (total density) that colonized onto ASU treatments (High plus, High, Moderate and Low) relative to mean total density of fauna in adjacent natural seagrass meadows (Amphibolis griffithii, Posidonia sinuosa and Cymodocea nodosa). Data are standardised to leaf surface area per $\mathrm{m}^{2}$.

Table 1: Differences in the density of macroinvertebrate found on ASUs were tested using one-way ANCOVA for Experiment 1 and two-way ANCOVA for Experiment 2. Macroinvertebrate densities were tested between high and low food and structure treatments (HH, HL and LL) in Experiment 1 and between different structural complexities (High plus, High, Moderate and Low) among different habitats (Amphibolis griffithii, Posidonia sinuosa and Cymodocea nodosa) in Experiment 2. In all cases $\mathrm{n}=5$. Bold $\mathrm{p}$ values indicate a significant difference.

Table 2: Mean leaf surface area and associated fauna densities (standardized against leaf surface area per $\mathrm{m}^{2} ; \mathrm{n}=5$ ) collected from three species of seagrass (Amphibolis griffithii, Posidonia sinuosa and Cymodocea nodosa), as well as defaunated A. griffithii seagrass 


\section{References}

August, P.V., 1983. The Role of Habitat Complexity and Heterogeneity in Structuring Tropical Mammal Communities. Ecology 64(6), 1495-1507.

Barbera-Cebrian, C., Tuya, F., Boyra, A., Sanchez-Jerez, P., Blanch, I., Haroun, R., 2005. Spatial variation in the structural parameters of Cymodocea nodosa seagrass meadows in the Canary Islands: a multiscaled approach. Botanica Marina 48, 122-126.

Bartholomew, A., Shine, L., 2008. Space size relative to prey width (Sp/Py) influences macrofaunal colonization of artificial structures Marine Ecology Progress Series 358, 95-102.

Beltman, J.B., Metz, J.A., 2005. Speciation: more likely through a genetic or through a learned habitat preference? Proceedings Of The Royal Society Of London Series B-Biological Sciences 272, 1455-1463.

Bologna, P.A.X., Heck, K.L., 1999. Macrofaunal associations with seagrass epiphytes - relative importance of trophic and structural characteristics. Journal Of Experimental Marine Biology And Ecology 242(1), 21-39.

Borowitzka, M., Lavery, P., van Keulen, M., 2006. Epiphytes of Seagrasses. In: Larkum, A.W., Orth, R., Duarte, C. (Eds.), Seagrasses: Biology, Ecology and Conservation. Springer, Dordrecht, pp. 441-461.

Bostrom, C., Mattila, J., 1999. The relative importance of food and shelter for seagrass-associated invertebrates: a latitudinal comparison of habitat choice by isopod grazers. Oecologia 120, 162-170.

Brawley, S., Aday, W., 1981. The effect of micrograzers on algal community structure in a coral reef microcosm. Marine Biology 61, 167-177. 
Brearley, A., Kendrick, A.J., Walker, D., 2008. How does burrowing by the isopod Limnoria agrostisa (Crustacea: Limnoriidae) affect the leaf canopy of the southern Australian seagrass Amphibolis griffithii? Marine Biology 156, 6577.

Cambridge, M., 1999. Growth strategies of Rottnest Island seagrasses. In: Walker, D.I., F.E., W. (Eds.), The seagrass flora and fauna of Rottnest Island, Western Australia. Western Australian Museum, Perth, pp. 1-24.

Cambridge, M.L., Kuo, J., 1979. 2 New Species Of Seagrasses From Australia, Posidonia-Sinuosa And Posidonia-Angustifolia (Posidoniaceae). Aquatic Botany 6(4), 307-328.

Cardoso, P.G., Raffaelli, M.A., Pardal, M.A., 2007. Seagrass beds and intertidal invertebrates: an experimental test of the role of habitat structure Hydrobiologia 575, 221-230.

Carruthers, T.J.B., 1999. Within canopy growth strategies of the two seagrass species Amphibolis griffithii (J. Black) den Hartog and Amphibolis antarctica (Labillardiere) Sonder \& Ascherson ex Ascherson. In: Walker, D.I., Wells, F.E. (Eds.), The Seagrass Flora and Fauna of Rottnest Island, Western Australia. Western Australian Museum, Perth, pp. 41-50.

den Hartog, C., 1970. Sea-grasses of the worldNorth Holland Publishing Company, Amsterdam, 276 pp.

Doropoulos, C., Hyndes, G.A., Lavery, P., Tuya, F., 2009. Dietary preferences of two seagrass inhabiting gastropods: Allochthonous vs autochthonous resources. Estuarine, Coastal and Shelf Science 83, 13-18. 
Ducker, S.C., Foord, N.J., Knox, R.B., 1977. Biology Of Australian seagrasses genus Amphibolis C Agardh (Cymodoceaceae). Australian Journal Of Botany 25(1), 67-95.

Duffy, J.E., Hay, M.E., 1991. Food and Shelter as Determinants of Food Choice by an Herbivorous Marine Amphipod. Ecology 72, 1286-1298.

Edgar, G.J., 1990a. The influence of plant structure on the species richness, biomass and secondary production of macrofaunal assemblages associated with Western Australian seagrass beds. Journal of Experimental Marine Biology and Ecology 137, 215-240.

Edgar, G.J., 1990b. Population regulation, population dynamics and competition amongst mobile epifauna associated with seagrass. Journal of Experimental Marine Biology And Ecology 144(2-3), 205-234.

Edgar, G.J., Robertson, A.I., 1992. The influence of seagrass structure on the distribution and abundance of mobile epifauna - pattern and process in a Western-Australian Amphibolis bed. Journal of Experimental Marine Biology and Ecology 160(1), 13-31.

Espino, F., Boyra, A., Tuya, F., Haroun, R., 2006. Guia visual de Especies Marina de CanariasOceanografica, Gran Canaria.

Gartner, A., Lavery, P., McMahon, K., Brearley, A., Barwick, H., 2010. Light reductions drive faunal changes in Amphibolis griffithii seagrass habitat. Marine Ecology Progress Series 401, 87-100.

Hannan, C.A., 1984. Planktonic larvae may act like passive particles in turbulent nearbottom flows. Limnology and Oceanography. Limnology and Oceanography 29, 1108-1116. 
Heck, K.L., Orth, R.J., 2005. Predation in Seagrass Meadows. In: Larkum, A.W.D. (Ed.), Seagrass Biology. Springer, The Netherlands, pp. 1-13.

Hemminga, M.A., Duarte, C.M., 2000. Seagrass ecologyCambridge University Press, Cambridge, 298 pp.

Hewitt, J.E., Thrush, S.F., Dayton, P.K., 2008. Habitat variation, species diversity and ecological functioning in a marine system. Journal of Experimental Biology and Ecology 366, 116-122.

Horinouchi, M., Mizuno, N., Jo, Y., Fujita, M., Sano, M., Suzuki, Y., 2009. Seagrass habitat complexity does not always decrease foraging efficiencies of piscivorous fishes. Marine Ecology Progress Series 337, 43-49.

Howard, R.K., Edgar, G.J., 1994. Seagrass meadows. In: Hammond, L.S., Synnot, R.N. (Eds.), Marine Biology. Longman Cheshire, Melbourne, pp. 257-271.

Hyndes, G.A., Lavery, P.S., 2005. Does transported seagrass provide an important trophic link in unvegetated, nearshore areas? Estuarine Coastal And Shelf Science 63(4), 633-643.

Jernakoff, P., Nielsen, J., 1997. The relative importance of amphipod and gastropod grazers in Posidonia sinuosa meadows. Aquatic Botany 56(3-4), 183-202.

Jernakoff, P., Nielsen, J., 1998. Plant-animal associations in two species of seagrasses in Western Australia. Aquatic Botany 60, 359-376.

Jernakoff, P., Brearley, A., Nielsen, J., 1996. Factors affecting grazer-epiphyte interactions in temperate seagrass meadows. Oceanography and Marine Biology Annual Review 34, 109-162.

Kitting, C.L., Fry, B., Morgan, M.D., 1984. Detection of inconspicuous epiphytic algae supporting food webs in seagrass beds. Oecolgia 62, 145-149. 
Klumpp, D.W., Howard, R.K., Pollard, D.A., 1989. Trophodynamics and nutritional ecology of seagrass communities. In: Larkum, A.W.D., McComb, A.J., Shepherd, S.A. (Eds.), Biology of seagrasses: a treatise on the biology of seagrasses with special references to the Australian region. Elsevier, Amsterdam, pp. 394-457.

Klumpp, D.W., Salitaepinosa, J.S., Fortes, M.D., 1992. The role of Epiphytic periphyton and macro-invertebrate grazers in the trophic flux of a tropical seagrass community. Aquatic Botany 43, 327-349.

Lavery, P., McMahon, K., Mulligan, M., Tennyson, A., 2009. Interactive effects of timing, intensity and duration of light reduction on Amphibolis griffithii. Marine Ecology Progress Series, 394, 21-33.

Lavery, P.S., Vanderklift, M.A., 2002. A comparison of spatial and temporal patterns in epiphytic macroalgal assemblages of the seagrasses Amphibolis griffithii and Posidonia coriacea. Marine Ecology Progress Series 236, 99-112.

Longstaff, B.J., Dennison, W.C., 1999. Seagrass survival during pulsed turbidity events: the effects of light deprivation on the seagrasses Halodule pinifolia and Halophila ovalis. Aquatic Botany 65, 101-121.

McCoy, E.D., Bell, S.S., 1991. Habitat structure: the evolution and diversification of a complex topic. In: Bell, S.S., McCoy, E.D. (Eds.), Habitat Structure: the Physical Arrangement of Objects in Space. Chapman and Hall, New York, pp. $3-27$.

Nakaoka, M., 2005. Plant-animal interactions in seagrass beds: ongoing and future challenges for understanding population and community dynamics. Population Ecology 47, 167-177. 
Orth, R.J., Heck, K.L., van Montframs, J., 1984. Faunal communities in seagrass beds - a review of the influence of plant structure and prey characteristics on predator prey relationships. Estuaries 7(4A), 339-350.

Quinn, G.P., Keough, M.J., 2002. Experimental design and data analysis for biologistsCambridge University Press, Cambridge, 537 pp.

Reyes, J., Sanson, M., 2001. Biomass and Production of the Epiphytes on the Leaves of Cymodocea nodosa in the Canary Islands. Botanica Marina 44(4), 307-313.

Sirota, L., Hovel, K.A., 2006. Simulated eelgrass Zostera marina structural complexity: effects of shoot length, shoot density, and surface area on the epifaunal community of San Diego Bay, California, USA. Marrine Ecology Progress Series 326, 115-131.

Tuya, F., Martin, J., Luque, A., 2006. Seasonal cycle of a Cymodocea nodosa seagrass meadow and of the associated ichthyofauna at Playa Dorada (Lanzarote, Canary Islands, eastern Atlantic). Ciencias Marinas 32(4), 695-704.

Virnstein, R.W., Nelson, W.G., Lewis, F.G., Howard, R.K., 1984. Latitudinal patterns in seagrass epifauna: do patterns exist, and can they be explained? Estuaries 7, $310-330$.

Vumazonke, L., Pakhomov, E., Froneman, P., McQuaid, C., 2003. Diet and daily ration of male and female caridean shrimp Nauticaris marionis at the Prince Edward Archipelago Polar Biology, 1-7.

Walker, D.I., Dennison, B., Edgar, G., 1999. Status of Australian seagrass research and knowledge. In: Butler, A., Jernakoff, P. (Eds.), Seagrass in Australia: strategic review and development of an R \& D plan. CSIRO Publishing, Collingwood, pp. 1-24. 
Warfe, D., Barmuta, L., 2006. Habitat structural complexity mediates food web dynamics in a freshwater macrophyte community. Oecologia 150, 141-154.

Waycott, M., Duarte, C., Carruthers, T., R, O., Dennison, W., Olyarnik, S., Fourqurean, J., Heck, K., Hughes, A.R., Kendrick, G.A., Kenworthy, W., Short, F.T., Williams, S.L., 2009. Accelerating loss of seagrasses across the globe threatens coastal ecosystems. Proceedings Of The National Academy Of Sciences Of The United States Of America 106(30), 12377-12381.

Wylie, C., Paul, V., 1988. Feeding preferences of the surgeonfish Zebrasoma flavescens in relation to chemical defences of tropical algae. Marine Ecology Progress Series 45, 23-32. 